\title{
Using Fund Transfer Pricing as a Performance Measurement System in the Financial Service Industry
}

\author{
Vincent Bicudo de Castro ${ }^{\mathrm{a}}$, Tiago Leote $^{\mathrm{b}}$, Maryam Safari ${ }^{\mathrm{c}}$ \\ ${ }^{a}$ Deakin Business School, Australia \\ ${ }^{b}$ IBMEC Business School, Brazil \\ ${ }^{c}$ RMIT University, Australia
}

\begin{abstract}
As a response to the financial crisis of 2007-2008, financial service industry regulators have commonly requested financial service industry to implement fund transfer pricing (FTP) mechanisms. Despite the importance of the topic as highlighted in the practitioners' literature since the 2000s, the use of FTP as a performance measurement system has been understudied. To add to our understanding of such mechanisms in the financial service industry, this paper demonstrates, through an analytical model, how FTP can be used as a performance measurement system in financial institutions. More importantly, this paper illustrates how FTP can be used for overcoming the distortions caused due to the transfer of funds between the business units.

Keywords: Management Accounting; Performance Measures; Transfer Pricing

Acknowledgements: The authors gratefully acknowledge helpful comments and suggestions received from the editor and anonymous reviewers on earlier versions of the paper.
\end{abstract}

\section{Introduction}

Performance measurement systems are key factors in ensuring the successful implementation of company strategies and techniques in pursuit of its goals (Ferreira \& Otley, 2009). In the 2000s, the discussion regarding performance measurement systems and performance measures have grown, as evidenced by the large portion of literature in 
management accounting investigating balanced scorecards (Hoque, 2014), non-financial performance measures (Hussain \& Hoque, 2002), and more recently the subjectivity of performance measures (Bicudo de Castro, 2017). The increased attention to such a topic by professionals, consultants, and academics reflects the pressures that result from the vigorous competition in the financial service industry. This, in turn, forces the financial institutions to improve their performance measurement systems to survive.

Several contemporary studies by management accounting scholars discuss the need for comprehensive and multi-dimensional performance measurement systems in organisations (Ferreira \& Otley, 2009; Hall, 2008; Kaplan \& Norton, 1996). Currently, non-financial performance measures have received considerable attention from management accounting scholars (Hussain, Gunasekaran, \& Islam, 2002). However, the use of non-financial performance measures is deeply associated with subjectivity in performance evaluation, which may lead to several concerns, such as conflicts between subordinates and supervisors (Bicudo de Castro, 2017; Ittner, Larcker \& Meyer, 2003).

This paper focuses on the under-researched topic of fund transfer pricing (FTP) and elaborates on how it can be used as a performance measurement system in financial institutions. Throughout this paper, FTP is addressed as a performance measurement system when discussed as a formal process for conveying the goals elicited by management. ${ }^{1}$ More specifically, when discussing the financial metrics used for comparing performance between business units, FTP is addressed as a financial performance measure. ${ }^{2}$ The FTP measures the contribution by each source of funding to the overall profitability in a financial institution (Dermine, 2013). Funds that go toward lending products are charged to asset-generating businesses whereas funds generated by deposit and other funding products are credited to liability-generating businesses (Bicudo de Castro, 2014).

\footnotetext{
${ }^{1}$ Performance measurement systems as "evolving formal and informal mechanisms, processes, systems, and networks used by organizations for conveying the key objectives and goals elicited by management, for the strategic process and ongoing management." (Ferreira \& Otley, 2009, p. 264)

${ }^{2}$ Performance measures as "the financial or nonfinancial measures (metrics) used at different levels in organizations to evaluate success in achieving their objectives, KSFs [key success factors], strategies and plans, and thus satisfying the expectations of different stakeholders." (Ferreira \& Otley, 2009, p. 271)
} 
Due to the financial crisis, particularly in the late 2000s, requirements for monitoring liquidity in financial institutions are implemented by many regulators, including FTP (Grant, 2011; Winckler \& Strietzel, 2017). Because of these regulatory requirements, FTP becomes a pervasive mechanism in the financial service industry. This paper contributes to management accounting literature in performance measurement systems in several ways and is beneficial to management accountants and practitioners, particularly to those working in the financial service industry. Regarding performance measurement systems, this paper introduces FTP to management accounting literature as a performance measurement system. Besides, this paper critically discusses how implementing FTP in a financial institution's performance measurement system is expected to mitigate distortions in performance caused due to the transfer of funds between the business units, contributing to a more comprehensive performance measurement system.

FTP can assist management accountants in identifying and addressing issues associated with distortions in business units' performance by developing a comprehensive performance measurement system that incorporates the effects of the business environment. Performance measures are potentially incomplete (Ittner, Larcker \& Meyer, 2003), and FTP can provide incremental information in the managerial decision process. This paper also contributes to the academic management accounting literature by focusing on the financial service industry. Most management accounting research in performance measurement systems is devoted to manufacturing industries, whilst very few studies have examined financial service industry, with few exceptions (e.g., Hussain et al., 2002; Hussain \& Hoque, 2002; Ittner, Larcker \& Randall, 2003). Furthermore, the analytical model presented in this paper provides an additional decision-making tool for management accountants working in the financial service industry.

The paper proceeds as follows. Section 2 presents a literature review on FTP and the set up for the use of FTP as a performance measure. Section 3 presents the paper's analytical model. Section 4 provides insights on how to use the paper's analytical model. Section 5 provides suggestions for future research and concludes the paper. 


\section{Literature Review}

\subsection{The Literature on Fund Transfer Pricing}

The way financial institutions manage and assess performance internally is closely intertwined with choices made in terms of operational structures. For instance, financial institutions organised as separate business units are expected to have different amounts for both origination and placement of funds, and the performance of these business units are therefore determined locally and heavily influenced by the local business environment (Peters, Duchesne, \& Slabari, 2015). This type of structure creates the need for a transfer price mechanism between the business units in order to avoid the distortion in performance caused due to the transferral of funds (through treasury) between the business units (Bicudo de Castro, 2014).

FTP is an important concept of how financial institutions determine the internal price when allocating funds across different business units. The Organisation for Economic Co-operation and Development (OECD) recommends that each financial institution should have its own FTP policy governing the basis on which funds are transferred between different business units and treasury (OECD, 2010). In financial institutions adopting FTP, the treasury is responsible for liquidity management and the internal pricing of funds to its different business units. One can think of the treasury as a financial institution within the financial institution: it buys funds from the business units, managing the liability side of the financial institution, and sells funds to the divisions that invest in banking assets (Grant, 2011).

FTP is a specific type of transfer pricing (cf. Arya \& Mittendorf, 2010) and is identified by the Organisation for Economic Co-operation and Development (OECD) as a treasury dealing (OECD, 2010). FTP measures the value of funds transferred through the treasury between business units within a financial institution. Internal exchanges that are measured by transfer prices result in (1) revenue for the business unit furnishing (i.e. selling) the funds and (2) costs for the business unit receiving (i.e., buying) the funds (Kawano, 2005). Considering a centralised organisation, internal trade is mandated and the fund transfer price unilaterally determined by the treasury (Holmstrom \& Tirole, 1991). Under centralization, the treasury maintains control over decisions and seeks to maximize the financial institutions' overall profit. As expected, given the centralized decision making, the transfer price has no effect on profit itself, only how it is split among the business units (Arya \& 
Mittendorf, 2010). Finally, financial institutions should manage FTP centrally through a treasury, with sufficient oversight provided by independent risk and financial control staff (Grant, 2011).

Before the financial crisis of 2007-2008, the pricing of liquidity costs was deemed immaterial and FTP was used by some financial services (mostly by practitioners) to measure performance internally (Winckler \& Strietzel, 2017). FTP deficiencies were identified during the financial crisis surrounding the incorrect consideration of liquidity when calculating performance. Consequently, regulators require financial institutions to develop and implement an appropriate FTP since 2008 (Grant, 2011; Ritchie, 2016; Winckler \& Strietzel, 2017). It is interesting to note that Hussain and Hoque (2002) suggest that economic constraints play an important role in shaping performance measures. There is evidence that FTP only come into attention recently due to the latest financial crisis, suggesting that economic constraints (e.g., liquidity issues) lead to the implementation of policies requiring FTP. The extensive list of regulators that discuss the implementation of FTP in financial institutions included the Basel Committee on Banking Supervision (BCBS), European Parliament and the European Commission (EC), the Committee for European Banking Supervisors (CEBS), the Institute for International Finance (IIF), the Counterparty Risk Management Policy Group III (CRMPGIII), the US Federal Reserve, and the US Federal Deposit Insurance Corporation (Grant, 2011; Ritchie, 2016; Winckler \& Strietzel, 2017).

Despite the regulators' requirement under a financial risk management focus, the implementation of FTP gives way for management accountants to play a more significant role within the financial service industry under a performance evaluation focus (Quan, 2009). Financial institutions can use FTP to evaluate the profitability of deposits and loans, and academics and antitrust authorities may use FTP to evaluate the degree of competition in the financial service industry (Dermine, 2013). Evidence of how FTP is relevant for management accountants is brought in a number of surveys. Drury (1998) finds the main reason given for using FTP in financial institutions is to evaluate the performance of business units. Based on his survey findings, Elliot (2018) suggests the main objectives of using FTP in financial institutions are strategy implementation and achievement of corporate goals. Further, Quan (2009) finds that measuring the performance of business units is as important as effectively managing the financial institution's risks, and Winckler and Strietzel (2017) finds a widespread consensus that FTP 
should be used for meeting liquidity (100\%), followed by strategic planning (70\%) and managing profit centres (70\%).

However, Elliot (2018) finds regulatory compliance is the main driver for financial institutions for implementing an FTP. Responses from the Winckler and Strietzel (2017) survey show that many FTP practices are largely deficient, as many financial institutions lack FTP policies, employ inconsistent FTP regimes, rely on off-line processes to manually update changes in funding costs, and have poor oversight of the FTP processes. As Elliot (2018) suggests from his survey results, perhaps users are unaware of how the FTP can feed into the performance measurement system. Therefore, this paper becomes a helpful guide for using fund transfer pricing as a performance measurement system in the financial service industry.

\subsection{Fund Transfer Pricing as a Performance Measurement System}

With increased competition from new products and delivery channels, financial institutions strive to succeed by improving their performance. To improve performance, most financial institutions adopt performance measurement systems which focus on financial performance measures such as cost reduction, return on investment, or net earnings (Krishnan, Ramaswamy, Meyer, \& Damien, 1999). A focus on financial performance measure happens because performance measurement systems are a set of performance measures which are jointly considered when evaluating the performance of an institution (Carlsson-Wall, Kraus, \& Messner, 2016). Financial institutions benefit by using a comprehensive and multi-dimensional performance measurement system (Ferreira \& Otley, 2009; Hall, 2008; Kaplan \& Norton, 1996). However, research has shown that the use of non-financial performance measures is deeply associated with subjectivity in performance evaluation, which may lead to several issues, such as distortions on subordinate performance evaluation, subordinate's reduced psychological empowerment and conflict between subordinates and supervisors (Bicudo de Castro, 2017; Ittner, Larcker \& Meyer, 2003). Hence, a call for more comprehensive performance measures for financial institutions, where perhaps a mix of financial performance measures could be used.

In addition to the matter regarding the adoption of comprehensive performance measures, there is also a concern regarding the distortion in performance between business units in the financial service industry. For 
instance, considering two business units within a financial institution, where revenue comes from furnishing (i.e. selling) funds and costs come from receiving (i.e., buying) funds, there will be a distortion on unit-level performance. This distortion is due to one business unit using another's funds for its operations. This distortion happens because the business unit short of funds will record a higher financial performance whereas the business unit with an excess of funds will record a lower financial performance (Bicudo de Castro, 2014). Therefore, the manager of a business unit operating short of funds will likely receive a better performance evaluation than the manager of a business unit operation with an excess of funds. This happens since senior managers tend to evaluate managers positively (negatively) when the outcome is positive (negative), regardless of whether the actions taken to achieve the results were appropriate (Ittner, Larcker \& Meyer, 2003). For instance, a business unit may perform better (i.e. have higher ratios) than another business unit because it operates in an area with a higher level of customers' income or faces less competition.

FTP can tackle this distortion by accounting for funds transferred through the treasury between business units within a financial institution. Although FTP has been present in practitioners' literature since the 2000s, management accountants have neglected this potential performance measure. FTP has been discussed by practitioners from financial institutions (Kawano, 2005; Kocakulah \& Egler, 2006), organisations such as SAP (Levey, 2008), PwC (Tumasyan, 2012), Deloitte (Peters et al., 2015), and government bodies (Grant, 2011; Rime, Schrimpf, \& Syrstad, 2017). ${ }^{3}$ Given the increasing relevance of liquidity analysis, FTP is discussed in the finance literature (Grant, 2011; La Ganga \& Trevisan, 2010; Rime et al., 2017) and the viewpoint of FTP for management accountants is briefly discussed in practitioners' publications such as Rice and Kocakulah (2004) and Bicudo de Castro (2014).

FTP is relevant for measuring the financial performance of business units as the literature regarding financial services often investigates the link between operational variables and performance measures, with a discussion of which business units are efficient (Elliot, 2018; Krishnan et al., 1999). There is evidence that management accountants in the financial service industry are willing to use FTP as a performance

\footnotetext{
${ }^{3}$ An example of practitioners' journal, which has several articles discussing FTP, is the Journal of Performance Management, published by the Association for Management Information in Financial Services (AMIfs).
} 
measure (Winckler \& Strietzel, 2017), and management accountants in the financial service industry seem to be firmly committed to financial measures for measuring performance (Hussain et al., 2002; Hussain \& Hoque, 2002).

\section{Analytical Model}

The analytical modelling methodology used in this paper is adapted from Arya and Mittendorf (2010) considering the specificities of FTP. This is in response to the need for a framework to demonstrate the use of FTP for measuring performance. There is evidence that the complexity of the FTP methodology is correlated with the organisation's business model (Winckler \& Strietzel, 2017). The FTP methodology used in this paper is a foundation approach (Dermine, 2013) using matched-maturity (Rime et al., 2017) and a single pool (Kawano, 2005). A foundation approach uses equivalent (undefined) maturity for the marginal return of assets and liabilities (Dermine, 2013), a matched-maturity FTP considers assets and liabilities having the same maturity, and is the most commonly used method currently considered by practitioners (Dermine, 2013; 2016; Rime et al., 2017), and finally, a single pool assumes that all funds transferred are accounted for uniformly as a single pool through the treasury (Kawano, 2005). Consequently, the analytical model considers one pool of funds transferred from excess deposits in one business unit to loans in another business unit, where the deposits and loans have the same maturity and treasury has only one price for accounting this transferral of funds.

The presented analytical model is suitable for addressing management accounting issues regarding the distortion of performance between business units in the financial service industry that are short of funds and business units with excess funds (Bicudo de Castro, 2014). The elegance of this analytical model lies in its simplicity and high explanatory power. Considering an analytical model for setting a price for transferring funds throughout the treasury within a centralised organization has its benefits when compared to traditional transfer pricing analytical models. An FTP analytical model does not concern about the uniqueness of the good, its quality, asymmetry of information, or marginal cost information (Arya \& Mittendorf, 2010; Holmstrom \& Tirole, 1991). The solution for traditional transfer pricing analytical models becomes trivial as there is a competitive market for money that can provide a relevant price reference (Holmstrom \& Tirole, 1991). For 
transfer pricing models, the first instinct is to set the transfer price equal to marginal cost (Hirshleifer, 1956), consequently, to properly charge for funds, financial institutions should charge rates based on their marginal cost of funds and match to the maturity of the product or business activity at origination (Grant, 2011). For this current FTP analytical model, maturity ceases to be a problem in as the model uses products with undefined maturity.

The variables used in this analytical model are the fund interest cost $\mathrm{C}_{\text {base, }}$, the fund transfer price $\mathrm{C}$, the fund rate of return $\mathrm{X}$, the business unit $n$ investments $\mathrm{Q}_{n e}$, the business unit $n$ funds $\mathrm{Q}_{n \mathrm{c}}$, and the funds transferred between unit $n$ and $i$, namely $\mathrm{Q}_{n i}$.

Figure 1. FTP with two business units and treasury

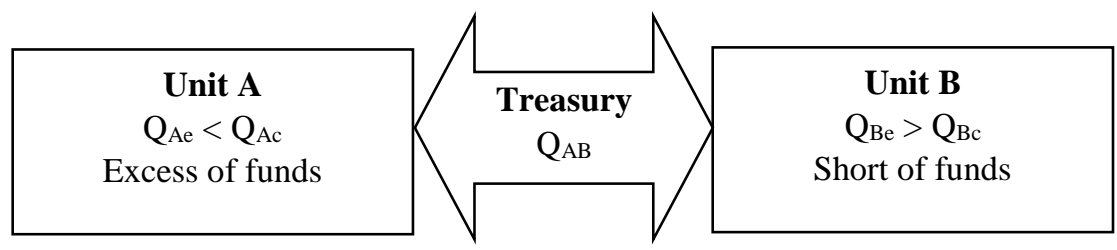

Assumptions for a model of FTP between two business units, namely unit $\mathrm{A}$ and $\mathrm{B}$, are that:

- The fund rate of return $\mathrm{X}$ and fund interest cost $\mathrm{C}_{\text {base }}$ are exogenous to the analytical model.

- Business unit $\mathrm{A}$ has a given amount of investments $\mathrm{Q}_{\mathrm{Ae}}$ and funds $\mathrm{Q}_{\mathrm{Ac}}$, and business unit $\mathrm{B}$ has a given amount of investments $\mathrm{Q}_{\mathrm{Be}}$ and funds $\mathrm{Q}_{\mathrm{Bc}}$.

- Business unit $\mathrm{A}$ has exceeding funds $\left(\mathrm{Q}_{\mathrm{Ae}}<\mathrm{Q}_{\mathrm{Ac}}\right)$ whereas business unit $B$ is short of funds $\left(\mathrm{Q}_{\mathrm{Be}}>\mathrm{Q}_{\mathrm{Bc}}\right)$.

- From the perspective of the financial institution, the total amount of investments is equal to the total amount of funds $\left(\mathrm{Q}_{\mathrm{Ac}}-\mathrm{Q}_{\mathrm{Ae}}=\mathrm{Q}_{\mathrm{AB}}=\right.$ $\left.\mathrm{Q}_{\mathrm{Be}}-\mathrm{Q}_{\mathrm{Bc}}\right)$.

- Through the perspective of the business units, all excess funds which are not transferred between the business units are reinvested on a fund interest cost investment (i.e., zero-sum game for the business unit, as 
no interest gains from investing the excess funds, and a loss to the financial institution).

- Through the perspective of the business units, all short funds which are not obtained between business units are obtained on a fund rate of return cost (i.e., zero-sum game for the business unit, as the cost of obtaining the fund, is equal to the profit with the investment, and a loss to the financial institution).

The assumptions allow the model to focus on an analysis of the FTP. Below is the profit maximization for each business unit, its constraints, and first-order conditions.

The profit maximization for each business unit is as follows:

$$
\begin{aligned}
& \Pi_{\mathrm{A}}=\mathrm{Q}_{\mathrm{Ae}} \cdot \mathrm{X}+\mathrm{Q}_{\mathrm{AB}} \cdot \mathrm{C}-\mathrm{Q}_{\mathrm{Ac}} \cdot \mathrm{C}_{\mathrm{base}} \\
& \Pi_{\mathrm{B}}=\mathrm{Q}_{\mathrm{Be}} \cdot \mathrm{X}-\mathrm{Q}_{\mathrm{AB}} \cdot \mathrm{C}-\mathrm{Q}_{\mathrm{Bc}} \cdot \mathrm{C}_{\text {base }}
\end{aligned}
$$$$
\text { (equation 1) }
$$

The constraints for profit maximization are:

$$
\begin{aligned}
& \mathrm{Q}_{\mathrm{Ae}}+\mathrm{Q}_{\mathrm{AB}}=\mathrm{Q}_{\mathrm{Ac}} \\
& \mathrm{Q}_{\mathrm{Be}}=\mathrm{Q}_{\mathrm{AB}}+\mathrm{Q}_{\mathrm{Bc}}
\end{aligned}
$$$$
\text { (constraint 1) }
$$

Using the constraints for maximizing profit $\Pi_{n}$ for each business unit:

$$
\begin{aligned}
& \Pi_{\mathrm{A}}=\mathrm{Q}_{\mathrm{Ae}} \cdot \mathrm{X}+\mathrm{Q}_{\mathrm{AB}} \cdot \mathrm{C}-\left(\mathrm{Q}_{\mathrm{Ae}}+\mathrm{Q}_{\mathrm{AB}}\right) \cdot \mathrm{C}_{\text {base }} \\
& \Pi_{\mathrm{B}}=\left(\mathrm{Q}_{\mathrm{AB}}+\mathrm{Q}_{\mathrm{Bc}}\right) \cdot \mathrm{X}-\mathrm{Q}_{\mathrm{AB}} \cdot \mathrm{C}-\mathrm{Q}_{\mathrm{Bc}} \cdot \mathrm{C}_{\text {base }}
\end{aligned}
$$

(using constraint 1) (using constraint 2)

The first-order conditions:

$$
\begin{aligned}
& \delta \Pi_{\mathrm{A}} / \delta \mathrm{Q}_{\mathrm{Ae}}=\mathrm{X}-\mathrm{C}_{\text {base }}=0 \\
& \delta \Pi_{\mathrm{A}} / \delta \mathrm{Q}_{\mathrm{AB}}=\mathrm{C}-\mathrm{C}_{\text {base }}=0 \\
& \delta \Pi_{\mathrm{B}} / \delta \mathrm{Q}_{\mathrm{AB}}=\mathrm{X}-\mathrm{C}=0 \\
& \delta \Pi_{\mathrm{B}} / \delta \mathrm{Q}_{\mathrm{Bc}}=\mathrm{X}-\mathrm{C}_{\text {base }}=0
\end{aligned}
$$


Given the assumptions and constraints, the first-order conditions depict that the profit for business units will depend on fund interest cost $\mathrm{C}_{\text {base, }}$, fund transfer price $\mathrm{C}$, and fund rate of return $\mathrm{X}$.

The profit for business unit A:

$$
\begin{aligned}
& \delta \Pi_{\mathrm{A}} / \delta \mathrm{Q}_{\mathrm{Ae}}=\mathrm{X}>\mathrm{C}_{\text {base }} \\
& \delta \Pi_{\mathrm{A}} / \delta \mathrm{Q}_{\mathrm{AB}}=\mathrm{C}>\mathrm{C}_{\text {base }}
\end{aligned}
$$

The profit for business unit B:

$$
\begin{aligned}
& \delta \Pi_{\mathrm{B}} / \delta \mathrm{Q}_{\mathrm{Bc}}=\mathrm{X}>\mathrm{C}_{\text {base }} \\
& \delta \Pi_{\mathrm{B}} / \delta \mathrm{Q}_{\mathrm{AB}}=\mathrm{X}>\mathrm{C}
\end{aligned}
$$

The analytical model with two business units provides three insights. First, for both business units to maximize profit, the fund rate of return must be higher than the fund interest cost; $\mathrm{X}>\mathrm{C}_{\text {base. }}$. Second, for business unit A (excess of funds, $\mathrm{Q}_{\mathrm{Ae}}<\mathrm{Q}_{\mathrm{Ac}}$ ) to maximize profit; $\mathrm{C}>\mathrm{C}_{\text {base }}$ and maximize $\mathrm{Q}_{\mathrm{Ae}}$ and $\mathrm{Q}_{\mathrm{AB}}$ (given the assumption that $\mathrm{Q}_{\mathrm{Ae}}<\mathrm{Q}_{\mathrm{Ac}}$, consequently a business unit which has an excess of funds only needs to maximize $\mathrm{Q}_{\mathrm{Ae}}$ and $\mathrm{Q}_{\mathrm{AB}}$ ). And third, for business unit $\mathrm{B}$ (short of funds, $\mathrm{Q}_{\mathrm{Be}}>\mathrm{Q}_{\mathrm{Bc}}$ ) to maximize profit; $\mathrm{X}>\mathrm{C}$ and maximize $\mathrm{Q}_{\mathrm{Bc}}$ and $\mathrm{Q}_{\mathrm{AB}}$ (given the assumption that $\mathrm{Q}_{\mathrm{Be}}>\mathrm{Q}_{\mathrm{Bc}}$, consequently a business unit which is short of funds only needs to maximize $\mathrm{Q}_{\mathrm{Bc}}$ and $\mathrm{Q}_{\mathrm{AB}}$ ).

Overall, the financial institution and both business units will profit with $\mathrm{X}>\mathrm{C}_{\text {base }}$. However, the profit or loss between the two business units will depend on where the fund transfer price $C$ stands. Setting the fund transfer price $\mathrm{C}$ provides several scenarios. If the fund transfer price is equal to zero $\left(X>C_{\text {base }} \mid C=0\right)$, there is no record of the number of funds transferred between business units (i.e., $\mathrm{Q}_{\mathrm{AB}} \mathrm{C}=0$ ), which means that business unit $\mathrm{A}$ (excess of funds) will be recording a loss whereas business unit B (short of funds) will be recording a profit. This is equivalent to the findings of Arya and Mittendorf (2010) when measuring segment profitability in centralized organisations.

If fund transfer price is equal to fund interest $\operatorname{cost}\left(\mathrm{X}>\mathrm{C}=\mathrm{C}_{\text {base }}\right)$, the fund transfer price $\mathrm{C}$ becomes cheap for business unit $\mathrm{A}$ (excess of funds) and all income transferred $\mathrm{Q}_{\mathrm{AB}} \mathrm{C}$ will be exhausted paying for funds $\mathrm{Q}_{\mathrm{AB}} . \mathrm{C}_{\mathrm{base}}$. If fund transfer price is equal to fund rate of return $(\mathrm{X}=\mathrm{C}>$ 
$\mathrm{C}_{\text {base}}$ ), the fund transfer price $\mathrm{C}$ becomes expensive for business unit $\mathrm{B}$ (short of funds) and all return from investments $\mathrm{Q}_{\mathrm{AB}} . \mathrm{X}$ will be exhausted paying for funds $\mathrm{Q}_{\mathrm{AB}}$.C. If fund transfer price is higher than the fund rate of return $\left(\mathrm{C}>\mathrm{X}>\mathrm{C}_{\text {base }}\right)$, the fund transfer price $\mathrm{C}$ will be more expensive than the return from investments $\mathrm{X}$, which means that the business unit A (excess of funds) will be recording a profit whereas business unit B (short of funds) will be recording a loss.

\section{Discussion}

The OECD defines a fund transfer price set to zero $(\mathrm{C}=0)$ as 'free' capital because business units short of funds receive resources from the treasury free of charge. Given the importance of measuring the performance of business units and appropriate funding structure for its activities, the financial institution should document how business units have obtained the resources for its operations (OECD, 2010).

The profit of the financial institution is independent of which value is set for $\mathrm{C}$, however, the analytical model demonstrates how the performance of business units is severely impacted by $\mathrm{C}$. The analytical model shows that financial institutions not using FTP are not rewarding business units with excess of funds that are funding other business units that are short of funds (i.e., 'free' capital). If the fund transfer price is between fund interest cost and fund rate of return $\left(\mathrm{X}>\mathrm{C}>\mathrm{C}_{\text {base }}\right)$, both business units will record a profit. However, the amount of profit for the business units will depend on fund transfer price $\mathrm{C}$ and funds transferred $\mathrm{Q}_{\mathrm{AB}}$.

The set fund transfer price will depend on the overall strategy of the financial institution. If the strategy of the financial institution is to reward business units that have an excess of funds, the set fund transfer price should be $C=[X, \Omega]$. And if the strategy of the organization is to reward business units that are short of funds, the set fund transfer price should be $\mathrm{C}=\left[\Omega, \mathrm{C}_{\text {base }}\right]$. The $\Omega$ is calculated by setting equal profits for both business units (i.e., $\Pi_{\mathrm{A}}=\Pi_{\mathrm{B}}$ ) and is a weighted average between $\mathrm{X}$ and $\mathrm{C}_{\text {base }}$ defined as:

$$
\Omega=\frac{\left(X \cdot\left(Q_{B \varepsilon}-Q_{A \varepsilon}\right)+C_{b a s e} \cdot\left(Q_{A c}-Q_{B c}\right)\right)}{2 \cdot Q_{A B}}
$$


Setting a price for the funds transferred through treasury should consider the cost of obtaining such funds by tracing its source and determining the actual rate incurred (i.e., tracing approach) or regard the funds as contributing to the whole financial institution's funding needs, and not simply to a business unit's funding needs (i.e., fungibility approach) (OECD, 2010). As advised by the OECD, financial institutions should allocate margins between various business units within the financial institution in accordance with the arm's length principle (OECD, 2010). Through an economics perspective, the transfer price should be equal to marginal cost (Hirshleifer, 1956). On a practical approach, FTP may be set using an interest rate curve based on the marginal funding costs faced by the financial institution (Rime et al., 2017; Ritchie, 2016).

In all, the analytical model demonstrates how a given fund transfer price will impact the measured performance of business units based on whether such business units are short of funds or have an excess of funds. The key variable which should be considered for setting the fund transfer price is the strategy of the financial institution (i.e. corporate strategy). A high fund transfer price rewards business units that have an excess of funds and a low fund transfer rewards business units that are short of funds. Such a decision on setting a given fund transfer price might benefit business units which are short of funds, have an excess of funds, or using $\Omega$ for setting equal financial performance across business units.

\section{Conclusion}

The purpose of this paper is to introduce an analytical model for showing how FTP can be used as a performance measurement system in the financial service industry. Implementing FTP contributes to a more comprehensive and multi-dimensional performance measurement system, especially as FTP accounts for specificities of each business unit's environment (i.e., excess or short of funds). Using an analytical modelling methodology, this paper provides a unique insight regarding the design of performance measurement systems in the financial service industry and the impact on financial performance across business units. The elegance of this analytical model lies in its simplicity and great explanatory power allowing management accountants to consider the strategy of the financial institution for establishing a fund transfer price and an understanding of the impact of setting a given transfer price to business units with excess or short of funds. This paper demonstrates how FTP can be used for mitigating distortions in the financial 
performance of business units caused due to the transfer of funds between the business units. Finally, the set fund transfer price may depend on the overall strategy of the financial institution, whereas the strategy of the financial institution is to reward business units that have an excess of funds or business units that are short of funds. Consequently, the managerial decision can rely on incremental information for the decision process.

The practical implication of this paper most specifically lies in its benefits for management accountants where it introduces FTP mechanism as an additional performance measure and as a decisionmaking tool. Currently, most prior studies focus on financial risk management, whereas FTP has a high potential for the management accounting profession. This paper brings FTP into the field of management accounting by providing evidence of its usefulness for performance measure in financial institutions.

In addition, the paper should be of interest to management accounting scholars, for advancement possibilities in future research as well as replication possibilities in other settings. Considering what has been stated regarding the issues with subjectivity in performance evaluation linked with non-financial performance measures, an objective (less subjective) performance measure such as benchmarking interest rates among financial institutions through FTP comes at hand. Such performance measure follows the benchmarking strategy for financial institutions (Hussain et al., 2002) and avoids issues relating to subjectivity (Bicudo de Castro, 2017). This paper uses an analytical model which relies on a few assumptions. Such assumptions enable the analytical model to be simple yet offer a high explanatory power. One suggestion for future studies and further advancement of the analytical model is to include risk effects (e.g., Rime et al., 2017; Ritchie, 2016; Skoglundt, 2012) when measuring the performance of business units. Another suggestion for future studies would be developing a model for a multi-period setting, as suggested by Dermine (2016). 


\section{References}

Arya, A. and Mittendorf, B., (2010), "Input Markets and the Strategic Organization of the Firm", Foundations and Trends in Accounting, Vol. 5 No. 1, pp. 1-97.

Carlsson-Wall, M., Kraus, K. and Messner, M., (2016), "Performance Measurement Systems and the Enactment of Different Institutional Logics: Insights from a Football Organization", Management Accounting Research, Vol. 32, pp. 45-61.

Bicudo de Castro, V., (2014), "Using Fund Transfer Pricing for Comparing Financial Performance among Business Units", Journal of Performance Management, Vol. 25 No. 3, pp. 11-21.

Bicudo de Castro, V., (2017), "Unpacking the Notion of Subjectivity: Performance Evaluation and Supervisor Discretion", British Accounting Review, Vol. 49 No. 6, pp. 532-544.

Dermine, J., (2013), "Fund Transfer Pricing for Deposits and Loans, Foundation and Advanced", The Journal of Financial Perspectives, Vol. 1 No. 1, pp. 1-10.

Dermine, J., (2016), "Fund Transfer Pricing for Bank Deposits: The Case of Products with Undefined Maturity", Journal of Financial Transformation, Vol. 43, pp. 132-149.

Drury, C., (1998), "Management Accounting Information Systems in UK building societies", Service Industries Journal, Vol. 18 No. 2, pp. 125143.

Elliot, V., (2018), "Funds Transfer Pricing in Swedish Savings Banks: An Exploratory Survey", Scandinavian Journal of Management, Vol. 34 No. 3, pp. 289-302.

Ferreira, A. and Otley, D., (2009), "The Design and Use of Performance Management Systems: An Extended Framework for Analysis", Management Accounting Research, Vol. 20 No. 4, pp. 263-282.

Grant, J., (2011), "Liquidity Transfer Pricing: A Guide to Better Practice", Financial Stability Institute (FSI) Occasional Paper No. 10, pp. 1-58, available at https://www.bis.org/fsi/fsipapers10.pdf [Accessed 18 December 2019]. 
Hall, M., (2008), "The Effect of Comprehensive Performance Measurement Systems on Role Clarity, Psychological Empowerment and Managerial Performance", Accounting, Organizations and Society, Vol. 33 No. 2-3, pp. 141-163.

Hirshleifer, J., (1956), "On the Economics of Transfer Pricing", The Journal of Business, Vol. 29 No. 3, pp. 172-184.

Holmstrom, B. and Tirole, J., (1991), "Transfer Pricing and Organizational Form", Journal of Law, Economics and Organization, Vol. 7 No. 2, pp. 201-228.

Hoque, Z., (2014), "20 Years of Studies on the Balanced Scorecard: Trends, Accomplishments, Gaps and Opportunities for Future Research", British Accounting Review, Vol. 46 No. 1, pp. 33-59.

Hussain, M., Gunasekaran, A. and Islam, M., (2002), "Implications of Non-Financial Performance Measures in Finnish Banks", Managerial Auditing Journal, Vol. 17 No. 8, pp. 452-463.

Hussain, M. and Hoque, Z., (2002), "Understanding Non-Financial Performance Measurement Practices in Japanese Banks: A New Institutional Sociology Perspective", Accounting, Auditing \& Accountability Journal, Vol. 15 No. 2, pp. 162-183.

Ittner, C. D., Larcker, D. F. and Meyer, M. W., (2003), "Subjectivity and the Weighting of Performance Measures: Evidence from a Balanced Scorecard", The Accounting Review, Vol. 78 No. 3, pp. 725-758.

Ittner, C. D., Larcker, D. F. and Randall, T., (2003), "Performance Implications of Strategic Performance Measurement in Financial Services Firms", Accounting, Organizations and Society, Vol. 28 No. 7-8, pp. 715-741.

Kaplan, R. S. and Norton, D. P., (1996), Translating Strategy into Action: The Balanced Scorecard, Harvard Business School Press, Boston.

Kawano, R. T., (2005), "Funds Transfer Pricing", Journal of Performance Management, Vol. 18 No. 2, pp. 35-43.

Kocakulah, M. C. and Egler, M., (2006), "Funds Transfer Pricing: How to Measure Branch Profitability", Journal of Performance Management, Vol. 19 No. 1, pp. 45-56. 
Krishnan, M. S., Ramaswamy, V., Meyer, M. C. and Damien, P., (1999), "Customer Satisfaction for Financial Services: The Role of Products, Services, and Information Technology", Management Science, Vol. 45 No. 9, pp. 1194-1209.

La Ganga, P. and Trevisan, G., (2010), "Towards a new framework for liquidity risk", CAREFIN Research Paper No. 08/10, available at: https://ssrn.com/abstract=1798631 [Accessed 18 December 2019].

Levey, K., (2008), "Beyond Funds Transfer Pricing to Actionable Decision-Making", Journal of Performance Management, Vol. 21 No. 1, pp. 10-21.

OECD, (2010), 2010 Report on the Attribution of Profits to Permanent Establishments, available at: https://www.oecd.org/ctp/transferpricing/45689524.pdf [Accessed 18 December 2019].

Peters, J. P., Duchesne, A. and Slabari, O., (2015), "Funds Transfer Pricing: A Gateway to Enhanced Business Performance", Inside, Vol. 7, pp. 48-55, available at: https://www2.deloitte.com/content/dam/ Deloitte/lu/Documents/tax/lu-funds-transfer-pricing-03032015.pdf [Accessed 18 December 2019].

Quan, L., (2009), Funds Transfer Pricing and Performance Evaluation, PhD Dissertation, Bangor University, available at: http://e.bangor.ac.uk/ 4464/ [Accessed 18 December 2019].

Rice, J. D. and Kocakulah, M. C., (2004), "Funds Transfer Pricing: A Management Accounting Approach within the Banking Industry", Journal of Performance Management, Vol. 17 No. 2, pp. 3-13.

Rime, D., Schrimpf, A. and Syrstad, O., (2017), "Segmented Money Markets and Covered Interest Parity Arbitrage", Bank for International Settlements (BIS) Working Paper No. 651, pp. 1-76, available at: https://www.bis.org/publ/work651.htm [Accessed 18 December 2019].

Ritchie, I. F., (2016), Funding Liquidity Risk and Fund Transfer Pricing in Banking, $\mathrm{PhD}$ Dissertation, Heriot-Watt University, available at: https://www.ros.hw.ac.uk/handle/10399/3273 [Accessed 18 December 2019].

Skoglundt, J., (2012), "Modern Risk-Based Funds Transfer Pricing", Journal of Performance Management, Vol. 24 No. 3, pp. 3-24.

Tumasyan, H., (2012), "Revisiting Funds Transfer Pricing", available at: https://ssrn.com/abstract=2257081 [Accessed 18 December 2019]. 
Winckler, R. and Strietzel, M., (2017), "Funds Transfer Pricing: The Gateway to Managing the Bank within the Bank", Roland Berger Focus, April 2017, pp. 1-24, available at: https://www.rolandberger.com/ publications/publication_pdf/foc_funds_transfer_pricing_final.pdf [Accessed 18 December 2019]. 